\title{
High-Tech or Low-Tech? Impact of Assistive Technology in School Settings for Students with Visual Impairments: Review of Research
}

\author{
Sevgi Kirboyun \\ University of Arizona, USA
}

\begin{abstract}
This study aimed to examine the impact of assistive technology $(A T)$ on the reading and writing performance and the social life of students with visual impairments (VI). Seventeen studies carried out between 2000 and 2019 were reviewed. Results showed that using the advanced features of AT devices such as braille notetakers and Mountbatten Brailler helped developing reading and writing skills of students with VI through revising and editing writing. Also, the use of mainstream devices like laptops and cell phones with screen readers promoted social interaction because of portability and inconspicuousness. Results were classified according to the common characteristics of the findings of these studies, such as the advantages and disadvantages of AT. The advantages of AT were improved reading and writing skills, increased access to the Internet, and better developed social lives. Barriers that impacted on the use of AT were cost of equipment and a lack of training.
\end{abstract}

\section{Introduction}

According to the Individuals with Disabilities Education Act, 2004, AT is defined as "any item, piece of equipment, or product system, whether acquired commercially off the shelf, modified, or customized, that is used to increase, maintain, or improve functional capabilities of individuals with disabilities." Increasing knowledge regarding assistive technology (AT) allows students with visual impairment (VI) to overcome difficulties in their lives and offers them independence and autonomy concerning information management and access to communication [2]. Electronic reading aids, mobile phones, and computers with screen reader and screen magnification programs, for example, can be used to scan and enlarge text so that students with VI can more likely read news, use navigation techniques, and search on websites [4]. Therefore, AT devices can be effectively helping people with VI to overcome many societal and access barriers and can increase the opportunities for independence for individuals with VI [10]. For instance, screen readers enable individuals with VI to become active learners by allowing them greater access to all types of print materials and better able to read the documents independently. Likewise, there are many AT tools for people with low vision, such as video magnifiers. Individuals who have low vision can effortlessly watch videos, read, and write with these tools. In addition, these tools provide individuals who have low vision with many opportunities such as the ability to adjust the magnification, brightness, contrast, and color of the display to their liking.

Individuals with VI use all AT devices ranging from "high-tech" devices to "low-tech" devices. According to the National Assistive Technology Research Institute (2006), high-tech devices are defined as sophisticated electronics or computers, including diverse items such as screen magnification applications and text-to-speech readers. Low-tech devices are less sophisticated, are not electronic, and are adapted, such as eyeglasses, slates, and style.

Individuals with VI acquire knowledge of their environment mostly through the senses of touch and hearing [3]. High-tech AT provides students with VI a chance to gain access to information through both auditory and tactile methods. The use of high-tech AT devices such as a braille notetaker, a device designed for people with VI to complete tasks such as e-mail, Internet, and word processing with the use of speech and braille output which has a six-braille key entry. Those high-tech AT devices give students with VI sophisticated opportunities to engage in the writing process that are not possible with low-tech AT devices like the Perkins Braille Writer, a manual typewriter used for writing braille which also has a six key entry system [13]. Besides, the ability to access information using AT is essential for success in education [14]. For example, using low-tech AT devices, such as a Perkins Braille Writer, might mean that students spend too much time writing and accessing information [13]. High-Tech AT devices, such as a Mountbatten, which is an electronic braille writer that has Bluetooth to connect to a computer, and braille and voice output can facilitate tactual and auditory feedback for writing. Also, software that allows for the production of tactile versions of visual images (concrete maps, 
pictures, and graphs) enables people with VI access to information.

Without AT, children who are primarily braille readers have limited experiences with literacy until they go to the school, while their sighted peers have many opportunities for learning [6]. For this reason, AT devices play a critical role in the success of the academic lives of students with VI. Success with an AT device is determined by how well the device performs, how satisfied the user is with it, and whether the user actually uses it frequently [12]. Any article synthesizing the overall effects of the use of AT. The purpose of this literature review is to examine how AT impacts the reading/writing skills and social skills of students with VI by answering the following questions:

1. What impact does AT have on the reading and writing performance of students with VI?

2. How does AT impact the social life of students with $\mathrm{VI}$ ?

\section{Method}

Search terms used for this literature review included VI, blind, braille readers, low vision, disability, AT, literacy, reading skills, writing skills, effectiveness, impact, etc. The following databases were searched: Academic Search Complete, Education Abstracts, Educational Full Text, ERIC, PsycARTICLES, PsycINFO, Teacher Reference Center, University of Arizona Library system, and Google Scholar The inclusion criteria for the literature review were peer-reviewed articles published in English after 2000. Also, the articles have to indicate the use of AT by students with VI in both literacy and social skills. I found 17 articles that met the inclusion criteria. Participants in the research studies were students with VI, classroom teachers and teachers for students with VI (TVI). However, there were no criteria specified for the target population, such as age and number of participants, nor the duration of the study.

\section{Results}

Research on the effectiveness of AT is limited. Fifteen studies were included for this study. Five of the studies were conducted outside of the United States: Alves et al. [2] (Brazil), Ampratwum et al. [3] (Ghana), Baker, Milne, and Ladner [27] (Norway), Wong and Cohen [23], and Wong and Law [24] (Singapore) and 12 studies were conducted in the United States. The studies used different methodologies to collect data: qualitative research method, single subject design, case study, mixed method, Delphi method, and survey research. The most common method used to study AT was the interview. Other data collection methods were used, such as observations and document analysis. The size of participants varied from one study to another, numbering from one to 1005 . Table 1 includes the type of research design and the number of participants in each study.

The studies included in this review examined the effectiveness of AT in different areas: improving reading and writing skills [5], increasing access to Internet [6], and developing social skills [3]; [9]; [19]; [27].

\subsection{Reading and Writing}

As discussed above, six studies [2], [5], [6], [8], [13] investigated the impact of using AT devices on reading and writing skills.

Three of these studies [5], [6], [13] were conducted with elementary and high school students who were braille readers, and their TVIs. When students are provided with access to high-tech devices, such as braille note-taker, students with VI write for longer periods of time [13]. The researchers [13] investigated if using a Perkins Brailler versus a note-taker would impact the students' engagement during the writing process. Kamei-Hannan and Lawson [13] found that, over six weeks, three middle school students in grades 4 to 6 made gains in their writing as scored in the five assessed areas (ideas and content, organization, sentence fluency, conventions, and presentations). Bickford and Falco [5] evaluated if there were differences in students' outcomes for braille fluency when the instruction was provided with traditional braille media (printed Braille) or AT device (refreshable Braille). The results of the research [5] showed that there were no significant differences between the students' use of the refreshable braille display and the use of printed Braille. However, the refreshable braille display was preferred by both TVIs and students, because it was easier for editing mistakes. Besides, the results [5] showed that the auditory output of the refreshable braille display provided motivation and feedback for the students. Similarly, Cooper and Nichols [6] stated that hightech device (Mountbatten) was easier for the kindergarten students with VI to use, and the auditory outcome of the Mountbatten had a positive impact on the students' development of writing skills. Likewise, researchers [26] interviewed parents, teachers, and students with VI who use high-tech devices (SMART Brailler). The SMART Brailler is an electronic brailler that allows teachers and parents to read what students are typing by displaying, vocalizing, and brailling. The teachers reported that the SMART Brailler improved the accuracy and speed of the students who learn Braille. All the teachers indicated that the SMART Brailler helps their students learn Braille faster by allowing self-edit and correct errors, giving immediate auditory input, and engaging more of their senses [26]. 
Table 1. Summary of Studies

\begin{tabular}{|c|c|c|c|c|c|}
\hline Authors & Year & Method & Technology & Participants & Country \\
\hline $\begin{array}{l}\text { Ajuwon, } \\
\text { Meeks, } \\
\text { Shirley, \& } \\
\text { Okungu }\end{array}$ & 2016 & $S$ & $\begin{array}{l}\text { Electronic note-takers, } \\
\text { screen-reading software } \\
\text { programs, and screen- } \\
\text { enlarging programs and video } \\
\text { magnifiers. }\end{array}$ & $\begin{array}{l}165 \text { TVIs ( } 96.97 \% \text { women } \\
\text { and a mean age of } 48.25, \\
\text { average teaching } \\
\text { experience } 19.42 \text {, only } \\
6.7 \% \text { use AT) from Texas } \\
\text { Study; } \\
840 \text { TVIs }(90.95 \% \text { women } \\
\text { and a mean age of } 48.17 \text {, } \\
\text { average teaching } \\
\text { experience } 20.09 \text {, only } \\
6.67 \% \text { use AT) from } \\
\text { National Study. }(\mathrm{N}=1005)\end{array}$ & USA \\
\hline $\begin{array}{l}\text { Kelly, S. } \\
\text { M. }\end{array}$ & 2011 & $S$ & $\begin{array}{l}\text { Computer with screen } \\
\text { readers and screen- } \\
\text { enlargement software }\end{array}$ & $\begin{array}{l}\text { National Longitudinal } \\
\text { Transition Study } 2 \\
\text { (NLTS); young adults with } \\
\text { VI aged from } 13 \text { to } 16 . \\
(\mathrm{N}=94)\end{array}$ & USA \\
\hline $\begin{array}{l}\text { Morash \& } \\
\text { Siu }\end{array}$ & 2016 & $S$ & $\begin{array}{l}\text { Mainstream (iPads and } \\
\text { computers) and specialized } \\
\text { technology (ZoomText, Jaws, } \\
\text { Talking Typer, Victor } \\
\text { Streams, magnifiers, CCTVs }\end{array}$ & $\begin{array}{l}494 \text { Teachers from USA } \\
\text { and } 11 \text { teachers from } \\
\text { Canada. They teach as } \\
\text { itinerant teachers, TVI, } \\
\text { and other professions. } \\
\mathrm{N}=505\end{array}$ & USA \\
\hline $\begin{array}{l}\text { Zhou, } \\
\text { Parker, } \\
\text { Smith, \& } \\
\text { Griffin- } \\
\text { Shirley }\end{array}$ & 2011 & $S$ & $\begin{array}{l}\text { Screen readers, screen } \\
\text { magnifier software, Braille } \\
\text { translation software, CCTV, } \\
\text { video magnifier, Braille note- } \\
\text { taker, talking dictionary, } \\
\text { digital book reader, digital } \\
\text { recorder, Braille embosser. } \\
\text { Scanner, refreshable Braille } \\
\text { and Braille writer }\end{array}$ & TVIs. $(\mathrm{N}=20)$ & USA \\
\hline $\begin{array}{l}\text { Kamei- } \\
\text { Hannan \& } \\
\text { Lawson }\end{array}$ & 2012 & SSD & $\begin{array}{l}\text { Braille note-taker vs Perkins } \\
\text { Braille Writer }\end{array}$ & $\begin{array}{l}\text { Students with VI who } \\
\text { used Braille. Two } \\
\text { students are in the } 8^{\text {th }} \\
\text { grade and one student is } \\
\text { in the } 6^{\text {th }} \text { grade at a } \\
\text { specialist school for the } \\
\text { blind. }(N=3)\end{array}$ & USA \\
\hline $\begin{array}{l}\text { Cooper \& } \\
\text { Nichols }\end{array}$ & 2007 & MM & $\begin{array}{l}\text { Mountbatten Pro Braille } \\
\text { Writer }\end{array}$ & $\begin{array}{l}\text { Student- a TVIs pairs (10 } \\
\text { in } 2003-04 \text { and an } \\
\text { additional } 10 \text { in 2004-05) } \\
\text { were selected. } \\
\text { (kindergarten students } \\
\text { were primarily braille } \\
\text { readers) }(\mathrm{N}=20)\end{array}$ & USA \\
\hline
\end{tabular}




\begin{tabular}{|c|c|c|c|c|c|}
\hline Authors & Year & Method & Technology & Participants & Country \\
\hline $\begin{array}{l}\text { Farnsworth } \\
\& \\
\text { Luckner }\end{array}$ & 2008 & $\overline{M M}$ & $\begin{array}{l}\text { BrailleNote and Tiger Cub Jr. } \\
\text { embosser, the Kurzweil } \\
\text { software, and using the } \\
\text { flatbed scanner }\end{array}$ & $\begin{array}{l}\text { Student with VI in the } \\
\text { case study is a sixth- } \\
\text { grade student who used } \\
\text { braille in a general } \\
\text { education setting and his } \\
\text { parents and classroom } \\
\text { teachers. }(\mathrm{N}=1)\end{array}$ & Brazil \\
\hline D’Ándrea & 2012 & MM & $\begin{array}{l}\text { BrailleNote, Computer with } \\
\text { JAWS, Window Eyes, and } \\
\text { MAGIC, Victor Reader, Victor } \\
\text { Wave, Victor Stream, Victor } \\
\text { Vibe, Book Port, scanner, } \\
\text { Braille embosser, Brilliant 24, } \\
\text { Cell phone with screen } \\
\text { reader, Digital recorder, GPS } \\
\text { system, Perkins Braille } \\
\text { Writer, Braille label maker, } \\
\text { Cassette tape player, Books } \\
\text { on tape and CD, Talking } \\
\text { Calculator, Electronic books, } \\
\text { RFB\&D and Web Braille, } \\
\text { Franklin Language, } \\
\text { Master/Talking Dictionary }\end{array}$ & $\begin{array}{l}\text { Students with } \mathrm{VI} \text { aged } \\
\text { from } 16 \text { to } 22 \text { and were } \\
\text { enrolled in an academic } \\
\text { school program at either } \\
\text { college or high school. } \\
(\mathrm{N}=12)\end{array}$ & USA \\
\hline $\begin{array}{l}\text { Wong \& } \\
\text { Law }\end{array}$ & 2016 & QR & $\begin{array}{l}\text { Screen reader (JAWS, } \\
\text { NVDA, and Voiceover), } \\
\text { screen magnification device, } \\
\text { Braille note-taker, and video } \\
\text { magnifier. }\end{array}$ & TVIs. $(\mathrm{N}=4)$ & Singapore \\
\hline $\begin{array}{l}\text { Wong \& } \\
\text { Cohen }\end{array}$ & 2011 & QR & $\begin{array}{l}\text { CCTV, magnifier, text-to- } \\
\text { speech devices, screen } \\
\text { reader and computer screen } \\
\text { enlargement software. }\end{array}$ & $\begin{array}{l}11 \text { students with VI ( } 8 \\
\text { to } 13 \text { years) and three } \\
\text { students have low } \\
\text { vision. }(\mathrm{N}=24)\end{array}$ & Singapore \\
\hline $\begin{array}{l}\text { Ampratwu } \\
\text { m, Offei \& } \\
\text { Ntoadura }\end{array}$ & 2016 & CS & JAWS & $\begin{array}{l}\text { Second year students } \\
\text { with VI ( } 23 \text { males, } 12 \\
\text { female). }(\mathrm{N}=35)\end{array}$ & Ghana \\
\hline $\begin{array}{l}\text { Bickford } \\
\text { \&Falco }\end{array}$ & 2012 & SSD & $\begin{array}{l}\text { Refreshable braille display vs } \\
\text { the Perkins Braille Writer }\end{array}$ & $\begin{array}{l}\text { TVIs who have at least } \\
\text { three years teaching } \\
\text { experience as specialist } \\
\text { teachers. (two teachers } \\
\text { were itinerant teachers, } \\
\text { two teachers worked at } \\
\text { residential school) and } \\
\text { nine students with } \mathrm{VI} \text { from } \\
6 \text { to } 8 \text { years old. }(\mathrm{N}=4)\end{array}$ & USA \\
\hline
\end{tabular}




\begin{tabular}{|c|c|c|c|c|c|}
\hline Authors & Year & Method & Technology & Participants & Country \\
\hline $\begin{array}{l}\text { Smith, } \\
\text { Kelley, } \\
\text { Maushak, } \\
\text { Griffin- } \\
\text { Shirley \& } \\
\text { Lan }\end{array}$ & 2009 & $\overline{Q R}$ & $\begin{array}{l}\text { Screen readers, screen } \\
\text { magnifier software, Braille } \\
\text { translation software, CCTV, } \\
\text { video magnifier, Braille note- } \\
\text { taker, talking dictionary, } \\
\text { digital book reader, digital } \\
\text { recorder, Braille embosser } \\
\text { and Braille writer. }\end{array}$ & $\begin{array}{l}\text { Participants from six } \\
\text { professional groups. } \\
(\mathrm{N}=30)\end{array}$ & USA \\
\hline $\begin{array}{l}\text { Shinohara } \\
\& \\
\text { Wobbrock }\end{array}$ & 2011 & QR & $\begin{array}{l}\text { Electronic note takers, } \\
\text { hearing aids, the Victor } \\
\text { Reader Stream (digital book } \\
\text { player), monocular, } \\
\text { magnifying glasses, and } \\
\text { video relay services. } \\
\text { mainstream devices, such as } \\
\text { the Apple iPhone and iPad, } \\
\text { netbooks, cell phones, } \\
\text { laptops, and desktop. }\end{array}$ & $\begin{array}{l}\text { Participants ( } 14 \text { were } \\
\text { visually impaired, four } \\
\text { deaf and hard of hearing, } \\
\text { one deaf-blind, one } \\
\text { cerebral-palsy). }(\mathrm{N}=20)\end{array}$ & USA \\
\hline $\begin{array}{l}\text { Michaelson } \\
\text { Matz, \& } \\
\text { Morgan }\end{array}$ & 2015 & QR & SMART Brailler & $\begin{array}{l}\text { Teachers, two braille } \\
\text { specialists, and the } \\
\text { assistant principal. }(\mathrm{N}=3)\end{array}$ & \\
\hline $\begin{array}{l}\text { Baker, } \\
\text { Milne, \& } \\
\text { Ladner }\end{array}$ & 2019 & QR & $\begin{array}{l}\text { Braille note-taker; refreshable } \\
\text { Braille display, magnification } \\
\text { tools and software, CCTV, } \\
\text { video magnifier, and screen } \\
\text { readers. }\end{array}$ & $\begin{array}{l}\text { TVIs (two work at the } \\
\text { school for the blind, one } \\
\text { works as itinerant } \\
\text { teacher). }(\mathrm{N}=3)\end{array}$ & Norway \\
\hline
\end{tabular}

S: Survey

SSD: Single Subject Design

QR: Qualitative Research

D'Ándrea [8] interviewed young students to investigate their attitudes towards AT as tools for learning in the classroom in high schools and colleges. In the study by D'Andrea [8], most of the students with VI reported that they use the high-tech device (braille note-taker) because it provides both auditory and braille feedback access to their textbooks and other instructional materials.

Alves et al. [2] surveyed TVIs about the impact of AT devices on the reading and writing skills of their students with VI. Alves et al. [2] reported that when the teachers were asked how the use of AT devices had increased the students' achievement in reading and writing, $84.2 \%$ of the teachers declared that AT devices were essential in enhancing the reading and writing skills of students with VI.

\subsection{Access to the Internet}

AT such as computer with screen readers or video magnifiers enable users to navigate the webpage by heading. Two studies [9], [19], explored the role of AT in using the Internet, on the academic work and on the social lives of people with VI.

3.2.1. Accessing information (via the Internet). The use of AT devices to access the Internet generally increased students' access to information independently just like their sighted peers. Farnsworth and Luckner [9] trained and observed a middle school braille reader student in the AT devices for access to the Internet. The training made it easier for the participant to interact with teachers by using e-mail with Microsoft attachments to send and receive homework and to access text information from websites for research projects and other assignments. 
Likewise, in the survey study of D'Andrea [8], most of the college students declared that their AT devices enabled better access to the Internet to do their assignments.

3.2.2. Social Skills. In addition to academic skills, students' social lives are benefited by the usability and functionality of AT. Social skills may be defined as an essential part of engaging in conversation with people, building efficient friendships, enjoying yourself in public, and succeeding in your career. Shinohara and Wobbrock [19] interviewed 20 individuals with VI, inquiring about their use of AT devices in their social life and at work, finding that the use of AT made individuals with VI more productive and independent in both areas of their lives. D'Andrea [8] asked college and high school students about their use of the Internet and found that most of them could create blogs, podcasts, and wiki pages for social purposes by using AT devices with the Internet. Shinohara and Wobbrock [19] found that since AT provides comparable access to the Internet, individuals with disabilities can balance complex relationships with their different environments, such as travel, work, friends, and education. The participants stated that the most used AT devices in social interactions were screen readers because mainstream technology devices, such as cell phones and laptops, were portable and inconspicuous [19]; [27].

The researchers [27] interviewed with TVIs to determine how children with VI are using AT devices in education settings and how TVIs are training them to use those AT devices at school. The results [27] showed that students with VI use high-tech devices such as Braille note-taker; refreshable Braille display (creating Braille characters by popping up dots through holes in a flat surface. Integrated with a keyboard); magnification tools and software; CCTV (video magnifier); and screen readers. The researchers [27] found that TVIs are training their students on a wide variety of mainstream devices with AT (e.g., iPads and computers with magnifiers and screen readers). The mainstream devices were often used an AT because having students using the same technology makes it easier for them to collaborate.

\subsection{Barriers to Using AT}

A number of barriers exist to the successful and effective use of AT among people with VI [3]; [20]. Barriers include limited instructional time [19]; [24], lack of time to interact with AT [23], lack of training for teachers [19]; [24], cost of equipment [15]; [3].

3.3.1. Lack of instruction at school. Braille instruction, teaching AT, and the role of the teacher in the use of AT are all important for the academic skills of students with VI [8]. Limited instructional time on how to use AT impacted on students' success [19];
[24]. In the survey, Kelly [15] found that only $42 \%$ of academically oriented high school students with VI use high-tech AT; students who eventually obtained a paid job were approximately 1.5 times more likely to use AT. Students with VI fall further behind their sighted peers every year because of lack of training about AT devices and the limited use of high-tech devices [15].

\subsubsection{Parental support in the use of AT.} Researchers indicated that the most critical factor in the adequate instruction of students about the use of AT was the involvement of parents [15]; [23]; [24]. Teachers reported that students with VI whose parents participated in parent meetings, programs, or parental education were approximately 1.4 times more likely to use AT devices than students whose parents did not attend [15]; when the students were at home, parents would help their children to use AT devices [15]; [24].

3.3.3. Limited access to use AT. Students stated different challenges due to the limited availability of AT. For instance, many students with VI explained their difficulties in keyboarding, such as the arrangement of the keys on the keyboard, the need for specific motor skills, and learning the combination of keys for shortcuts. The researchers suggested strategies that might help address those challenges, such as mental skills adopted by teachers to remember shortcuts, additional technology classes to learn the keys on the keyboards, and extra practice to develop motor skills; they also indicated that the training in and familiarity with using AT for students with VI were potential barriers [3]. TVIs reported that the school allowed only two hours per week to learn how to use AT, an insufficient amount of time to learn the advanced skills of using AT devices [24]. Furthermore, the use of high-tech AT devices both in school and at home has positive impacts on students' academic skills; however, the students used only hightech AT while at school, but they used low-tech AT both in school and at home [9].

3.3.4. Cost of equipment. The uneven allocation of equipment and poor access to computer resources were shown to be barriers to the use of information technology in schools [2]. In particular, students with VI who attended a public school have not yet adequately benefited from the use of high-tech AT devices because of limited access to AT devices in their school. Also, TVIs cited that cost as a concern for AT devices [27]. High school students with VI who attended residential schools were approximately 1.8 times more likely to use AT than those who did not attend a residential school [15]. As previously stated, the use of AT at home is often not affordable for students with VI [9]. 


\subsection{Barriers to Teaching Students to Use AT}

The survey research studies [1], [2], [16], [24], [25] examined the perspectives of TVIs regarding the use and effectiveness of high-tech AT. Three of the survey studies included both classroom teachers and TVIs as participants [1]; [16]; [25]. Only one study included in this review used the Delphi method, with 40 panelists, both TVIs and professors [20].

3.4.1. Lack of Training. In most of the studies, it was clear that a lack of knowledge by the teachers about AT had detrimental effects on the use of AT by students with VI [16]; [20]; [24]. Panelists (TVIs and professors) indicated that the lack of pre-service training about AT had a negative impact on student achievement [20]. The panelists stated that AT should have a high priority in higher education teacher training programs. Teachers reported that even though the National Institute of Education (the only teacher training institution in Singapore) provides training about teaching AT to all TVIs, there still remains a fundamental need for this to be included in teacher training [24]. Teachers stated that there needs to be more time and instruction on high-tech devices in the training programs for TVIs [1]. D'Andrea [7], Wong and Cohen [23], and Wong and Law [24] discussed that greater emphasis should be placed on training regarding AT in preparation programs. In the study by Wong and Law [24], the teachers agreed that there was a lack of training and instruction to teach AT devices, and teachers indicated that without a wellplanned and structured curriculum, student learning was limited by the teachers' restricted knowledge.

\section{Discussion}

This review of research revealed both the challenges and advantages of AT on social skills, using the Internet, and reading and writing skills of students with VI. Mainly, the following research questions were answered: (a) What impact does AT has on the reading and writing performance of students with VI? (b) How does AT impact the social life of students with VI?

The findings of this review indicated that the use of AT devices with advanced features, such as spell check and cut/copy/paste option, allows students with VI to revise, edit, and improve the overall quality of their writing products. Moreover, AT devices with advanced features make it more accessible to track, to locate information on a page, and to format sentences, paragraphs, and pages. Further, having additional input through touch and hearing reinforces the reading skills of students with VI. Since the results of the study shows that using high-tech AT devices had a positive effect on writing skills (faster, greater length, and higher quality passages), reading skills (revising and scanning), the expanded core curriculum must include an emphasis on using high-tech AT devices in the earlier age of students with VI [2]; [5]; [6]; [13]. Also, educators should focus on the need for AT in extra-curricular activities in the Individualized Education Program (IEP) meetings.

Several researchers (D'Andrea [8], Shinohara and Wobbrock [19] asserted that AT devices eliminated barriers for students with VI by allowing them the same access to information as sighted people. AT provided students with VI more interaction with their environment (traveling, working, learning, using email, and social networking). AT enables students with VI to do the same thing with their peers at the same time, both in class and in the workplace. For example, AT allows using Internet and access to written files in the digital version without waiting to print those files in Braille. Also, AT removes barriers between students with VI and their classmates by offering opportunities to work on the same document such as a google doc and track changes.

Individuals with VI prefer to use mainstream technology devices with screen readers as an AT tool because of their usability, cost, aesthetic appeal, and social acceptance [19]. Overall, this review demonstrated that even though AT devices have many barriers, students with VI improved their quality of life via the usability and functionality of AT.

It is essential to use AT devices both in school and at home, especially for elementary school students who are learning to read and write in order to enhance their efficiency in these skills [9]. However, most of the studies included in this review did not discuss the use of AT devices at home by elementary school students. It is essential to focus on to access to hightech AT devices only in school settings has a negative impact on reading and writing skills of students with VI. Attention needs to be paid to the training of TVIs regarding AT. Results demonstrated that the inclusion of family in AT training is another important factor in determining student performance in reading and writing. Some articles [15], [23], [24] explained that collaboration between parents and teachers would help students to be independent when using AT. Several researchers [8], [19] stated that individuals with VI preferred mainstream technology devices for their social life.

Lastly, the most of researchers did not address the software challenges. Only one researcher [3] indicated that using unlicensed screen reader (JAWS) software or flawed versions of the software (JAWS) in school caused some problems. Especially in a developing country, using unlicensed screen reader (JAWS) software causes some problems such as freezing screen, limited language selection, or shut down the program. 


\subsection{Implications for Practitioners and Researchers}

Despite the gains in students' writing quality and reading fluency, TVIs play more active roles in teaching how to use AT to students with VI compared to general education teachers [2]; [5]; [6]; [8]; [14]. Future studies should seek other solutions, such as a user guide that describes the necessary steps for using AT devices when students are learning how to use such a device. In this way, when students need help with the next step, they can check what is next without needing the help of TVIs. It might also be important to have an evaluation of students' learning skills by TVIs during the teaching of AT devices. Also, when comparing the impact of high-tech and low-tech AT devices on reading and writing skills, there might be compounding variables, such as student motivation and enthusiasm for the writing process. None of the authors explained how they chose the writing topics or how they arranged for students with VI to work on them. There is not a clear indication of whether all students had the same motivation for writing or for using AT devices.

When researchers interviewed TVIs and classroom teachers to learn about the advantages and challenges of AT for students with VI, the researchers did not observe the teachers while they were teaching in the classroom [1]; [2]; [8]; [16]; [24]; [25]. It is more important to ask how teachers actually teach AT in the classroom. Also, in higher education, teaching more courses in AT would be beneficial for TVIs.

Lastly, students with VI use mainstream technology devices as an AT tool because they are cheap and socially accepted. However, using mainstream technology as an AT tool causes some software problems. Even though these problems can have a negative impact on the social skills of students with VI in their daily life, there is a limited study of the software challenges of AT. In future studies, researchers should focus on the barriers presented by using software for mainstream technology devices with an AT device.

\section{References}

[1] P. M. Ajuwon, M. K. Meeks, Griffin-Shirley, N., \& Okungu, P. A., (2016). Reflections of teachers of visually impaired students on their assistive technology competencies. Journal of Visual Impairment \& Blindness, 110(2), pp. 128-134.

[2] C. C. D. F. Alves, G. B. M. Monteiro, S. Rabello, M. E R. F. S. Gasparetto, \& K. M. D. Carvalho, (2009). Assistive technology applied to education of students with visual impairment. Revista Panamericana de Salud Pública, 26 (2), pp. 148-152.

[3] J. Ampratwum, Y. N. Offei \& A. Ntoaduro, (2016). Barriers to the use of computer assistive technology among students with visual impairment in Ghana. Journal of Education and Practice, 29 (7), pp. 58-61.

[4] L. Barker, R. Thomas, G. Rubin \& A. Dahlmann-Noor, (2015). Optical reading aids for children and young people with low vision. Cochrane database of systematic reviews, (3) CD010987.

[5] J. O. Bickford \& R. A. Falco, (2012). Technology for early braille literacy: Comparison of traditional braille instruction and instruction with an electronic notetaker. Journal of Visual Impairment \& Blindness, 106(10), pp. 679-693.

[6] H. L. Cooper \& S. K. Nichols, (2007). Technology and early braille literacy: Using the mountbatten pro brailler in primary-grade classrooms. Journal of Visual Impairment \& Blindness, 101(1), pp. 22-31.

[7] F. M. D“Andrea, (2009). From carvings to computers: A history of tactile codes for people who are blind. The educator, XXI (2), pp. 5-9.

[8] F. M. D‘Andrea, (2012). Preferences and practices among students who read braille and use assistive technology. Journal of Visual Impairment \& Blindness, 106(10), pp. 585-596.

[9] C. R. Farnsworth \& J. L. Luckner, (2008). The impact of assistive technology on curriculum accommodation for a braille-reading student. Review: Rehabilitation Education For Blindness And Visual Impairment, 39 (4), pp. 171-187.

[10] M. A. Hersh \& M. A. Johnson, (2008). Disability and assistive technology systems. Assistive Technology for Visually Impaired and Blind People, pp. 1-50.

[11] Individuals with Disabilities Education Act. (n.d.). Springer Reference. doi:10.1007/springerreference_ 223925.

[12] J. W. Jutai, M. J. Fuhrer, M. J. Scherer, \& F. DeRuyter, (2005). Toward a taxonomy of assistive technology device outcomes. American Journal of Physical Medicine \& Rehabilitation, 84 (4), pp. 294-302.

[13] C. Kamei-Hannan \& H. Lawson, (2012). Impact of a braille-note on writing: Evaluating the process, quality, and attitudes of three students who are visually impaired. Journal of Special Education Technology, 27 (3), pp. 1-14.

[14] G. Kapperman \& J. Sticken, (2000). Assistive technology. In A. J. Koenig, \& M. C. Holbrook (Eds.), Foundations of education (2nd ed.): Volume II. Instructional strategies for teaching children and youths with visual impairments. (pp. 500-528). New York: AFB Press.

[15] S. M. Kelly, (2011). Assistive technology use by high school students with visual impairments: A second look at the current problem. Journal of Visual Impairment \& Blindness, 105, pp. 235-239.

[16] V. S. Morash \& Y. T. Siu, (2016). Social predictors of assistive technology proficiency among teachers of students 
with visual impairments. Transactions on Accessible Computing (TACCESS), 9 (2), pp. 1-27.

[17] What is Assistive Technology? (n.d.). Retrieved from http://natri.uky.edu/resources/fundamentals/defined.html.

[18] D. H. Rose, T. S. Hasselbring, S. Stahl \& J. Zabala, (2005). Assistive technology and universal design for learning: Two sides of the same coin. In D. Edyburn, K. Higgins, \& R. Boone (Eds.), Handbook of Special Education Technology Research and Practice (pp. 507518). Whitefish Bay, WI: Knowledge by Design.

[19] K. Shinohara \& J. O. Wobbrock, (2011). In the shadow of misperception: assistive technology use and social interactions. In Proceedings of the SIGCHI Conference on Human Factors in Computing Systems, (pp. 705-714).

[20] D.W. Smith, P. Kelley, N.J. Maushak, N. GriffinShirley \& W.Y. Lan, (2009). Assistive technology competencies for teachers of students with visual impairments. Journal of Visual Impairment \& Blindness, 103 (8), pp. 457-469.

[21] The Early Childhood Technical Assistance Center. (n.d.). Retrieved from http://ectacenter.org/topics/atech/ definitions.asp.

[22] The Early Childhood Technical Assistance Center. (n.d.). Retrieved from http://ectacenter.org/topics/atech/ definitions.asp.

[23] M. E. Wong \& L. Cohen, (2011). School, family and other influences on assistive technology use Access and challenges for students with visual impairment in Singapore. British Journal of Visual Impairment, 29(2), pp. 130-144.

[24] M. E. Wong \& J. S. Law, (2016). Practices of assistive technology implementation and facilitation: Experiences of teachers of students with visual impairments in Singapore. Journal of Visual Impairment \& Blindness, 110 (3), pp. 195200.

[25] L. Zhou, A. T. Parker, D. W. Smith \& N. GriffinShirley, (2011). Assistive technology for students with visual impairments: Challenges and needs in teachers' preparation programs and practice. Journal of Visual Impairment \& Blindness, 105 (4), pp. 197-210.

[26] K. J. Michaelson, L. Matz \& D. Morgan, (2015). Using a new electronic Brailler to improve Braille learning at the Florida school for the deaf and blind. Journal of Visual Impairment \& Blindness, 109(3), 226-231.

[27] C. M. Baker, L. R. Milne, \& R. E. Ladner, (2019). Understanding the Impact of TVIs on Technology Use and Selection by Children with Visual Impairments. In Proceedings of the 2019 CHI Conference on Human Factors in Computing Systems (p. 424). ACM. 